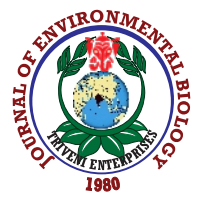

\title{
Performance of different Indian mustard (Brassica juncea) varieties with saline water and graded fertilizer doses under semi-arid conditions of Haryana
}

\author{
Priyanka', R. Prakash ${ }^{1 *}$, R. Yadav ${ }^{1}$, N. Kumar ${ }^{2}$ and A. Dhillon ${ }^{2}$ \\ 'Department of Soil Science, CCS HAU, Hisar- 125 004, India \\ ${ }^{2}$ Department of Agricultural Economics, CCS HAU, Hisar- 125 004, India \\ *Corresponding Author Email : ramsansahwa@@gmail.com
}

Paper received: 13.06 .2020

Revised received: 03.10 .2020

Accepted: 30.10 .2020

\section{Abstract}

Aim: The existing research was undertaken to approximate the significance of interactive effects of varieties $X$ fertilizer doses in mustard crop with saline water irrigation undersemi-arid conditions of Haryana.

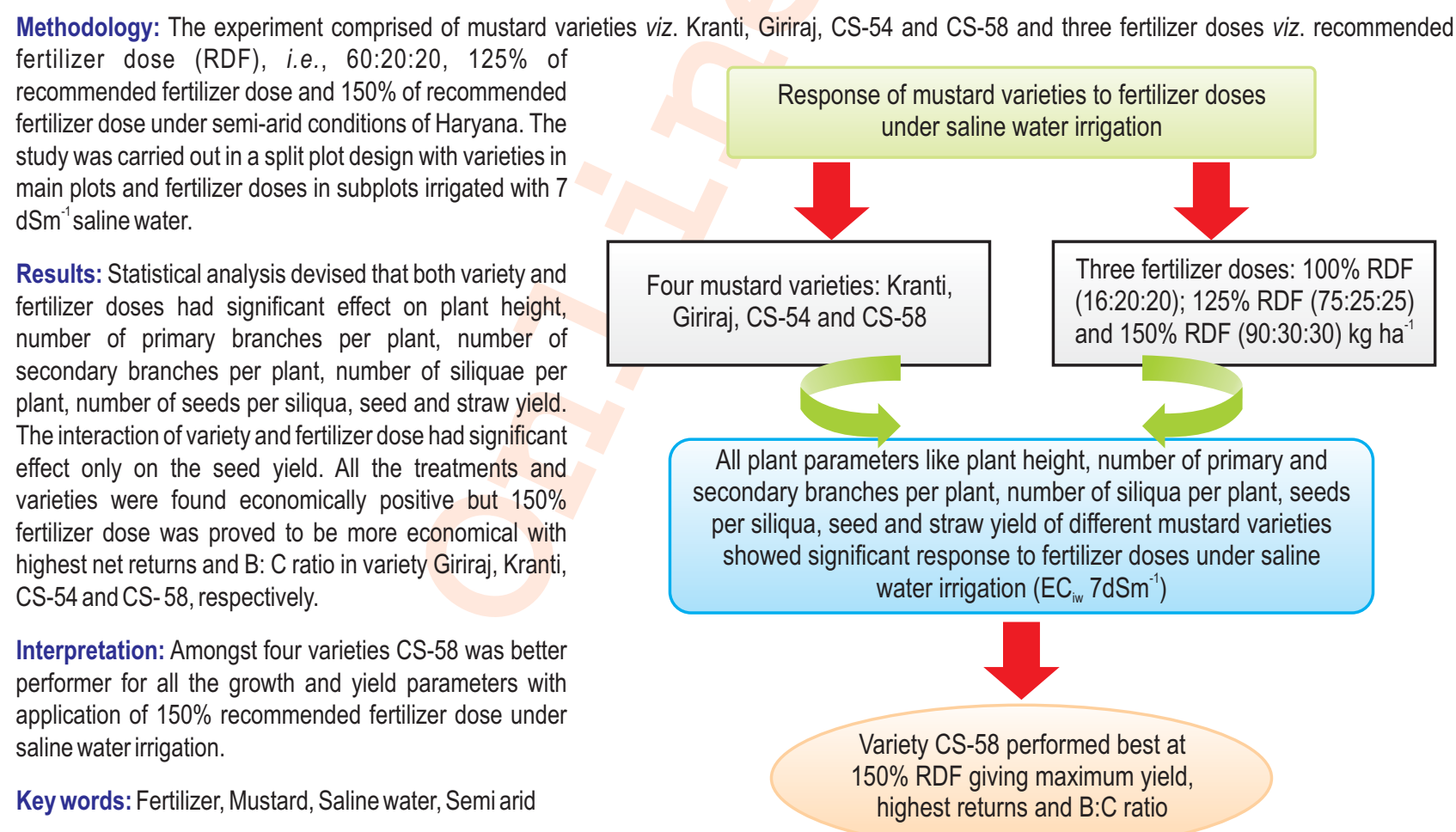

How to cite : Priyanka, R. Prakash, R. Yadav, N. Kumar and A. Dhillon: Performance of different Indian mustard (Brassica juncea) varieties with saline water and graded fertilizer doses under semi-arid conditions of Haryana. J. Environ. Biol., 41, 1599-1604 (2020). 


\section{Introduction}

Rapeseed/Mustard is the third most crucial source of edible oil globally after soybean and palm. The area, production and productivity of mustard in the world is 36.62 Mha, 72.41 MMTand 1.98 MTha $^{-1}$ (USDA, 2019), respectively. In India, rapeseed/mustard is the second important oil seed crop after groundnut and cultivated on an area of about 7.20 Mha with the production of 8.01 MMT and an average productivity of 1.11 MTha $^{-1}$ (USDA, 2019).Among the seven major oilseeds grown in India, rapeseed/mustard shares $28.6 \%$ in the total production of oilseeds. Indian mustard (Brassica juncea) is cultivated predominantly in the regions of Haryana, UP, Rajasthan, Gujarat and Madhya Pradesh. In Haryana, mustard is cultivated on 5.37 lakh ha area with almost 7.54 lakh tonnes of total production. The productivity of rapeseed/mustard is much lower in the state than its realizable yield potential. Although mustard is a salt tolerant crop among the oilseed crops but its productivity is highly affected by salinity (Ashraf and McNeilly, 2004).Hence, the yield of mustard under saline water irrigation can only be increased by adopting better management practices and counter balance fertilization. Usage of optimal fertilizer rates under stress conditions improves soil physico-chemical properties as it reduces the nutrient imbalance, and encourages better crop growth and development (Abumere et al., 2019). The use of synthetic fertilizers, particularly has been approximated to hike 19 to 48 per cent rise in oilseeds production. Among the essential nutrients, nitrogen and sulphur has substantial repercussions, particularly on the quality and quantity of seed. An adequate supply of nitrogen is strongly correlated with ontogeny of the crops. Sulphur is crucial for plants and emanated as the third necessary plant nutrient to oilseeds by playing multiple roles in their nutrition. Phosphorus is one of the most important components in crop nutrition and identified to play a key role in salinity-fertility interaction and heighten plant vigour in terms of salt tolerant capacity (Kumar et al., 2005). Furthermore, potassium is recognized to play an important part in plant endurance under salt stress conditions (Mahmood, 2011).Thus, external administering of salt-induced insufficient nutrients like $\mathrm{N}$, $\mathrm{P}, \mathrm{K}$ and $\mathrm{S}$ can alleviate the detrimental effect of salinity on crop growth (Abbasi et al., 2016). Moreover, there is a large variability in the meteorological and edaphic surroundings in the mustard growing regions of India, the selection of desired cultivars is essential as it benefits in improving the productivity. Improved mustard varieties stabilize seed and oil yield through insulation of cultivars against major abiotic and biotic stresses (Shekhawat et al., 2012). Upgraded mustard genotypes with salt tolerance are required for attaining ideal yield and extension of cultivated area under stress conditions.

In arid and semi-arid regions, surface irrigation water supplies and rainfall both are unpredictable and incompetent to fulfil crop water demand. Quality of groundwater in these domains is generally marginally saline $\left(2-6 \mathrm{dSm}^{-1}\right)$ to saline $\left(>6 \mathrm{dSm}^{-1}\right)$ and perhaps utilized to suffice crop water requirement if no detrimental effects on crops and soil eventuate. Among various irrigation management options, conjunctive use strategies such as blending and cyclic use have been universally applied around the globe (Chauhan et al., 2008; Sharma et al., 2013; Gupta and Gupta, 2015).In Hisar region of Haryana $9 \%, 3 \%$ and $88 \%$ of deep ground water are categorized as fresh $\left(<2 \mathrm{dSm}^{-1}\right)$, marginal $(2-6$ $\mathrm{dSm}^{-1}$ ) and saline (>6 dSm ${ }^{-1}$ ) quality (Gupta and Gupta, 2015). Therefore, the present study was carried out with saline water of $\mathrm{EC}_{\text {iw }} 7 \mathrm{dSm}^{-1}$ for irrigation in semi-arid region to study the effect of fertilizer doses on growth and economics of different mustard varieties.

\section{Materials and Methods}

The experimentation was accomplished during Rabi period 2017-18, to ascertain the impact of different fertilizer doses on growth and yield of different mustard varieties coupled with saline water for irrigation at CCS Haryana Agricultural University Research Farm, Department of Soil Science, Hisar. The experimental site was located at 29 $8^{\circ} \mathrm{N}$ latitude and $75^{\circ} 70^{\prime} \mathrm{E}$ longitude at an elevation of $215.2 \mathrm{~m}$ above mean sea level. The soil of research field was sandy loam in texture, low in organic carbon $(0.26 \%)$, available $\mathrm{N}\left(102.4 \mathrm{~kg} \mathrm{ha}^{-1}\right)$ and medium in available $\mathrm{P}\left(16.0 \mathrm{~kg} \mathrm{ha}{ }^{-1}\right), \mathrm{K}_{2} \mathrm{O}\left(245.50 \mathrm{~kg} \mathrm{ha}^{-1}\right)$ and somewhat alkaline in reaction ( $\mathrm{pH} 8.10$ ) with soil $\mathrm{EC}_{\mathrm{e}}$ of $3.18 \mathrm{dSm}^{-1}$. The agrometreological data related to the experimental site during rabi season 2017-18 revealed that the mean weekly rainfall ranged from 0 to $34.6 \mathrm{~mm}$, minimum temperature ranged from 3.2 to $17.5^{\circ} \mathrm{C}$ and maximum temperature ranged from 16.9 to $35.7^{\circ} \mathrm{C}$. The field experiment was conducted in split plot design with three replications, having four mustard varieties in main plot which includes Kranti, Giriraj, CS-54, CS-58, and three sub-plot treatments viz. $100 \%$ dose of fertilizer, $125 \%$ dose of fertilizer and $150 \%$ dose of fertilizer with application of saline water $\left(\mathrm{EC}_{\mathrm{iw}} 7\right.$ $\mathrm{dSm}^{-1}$ ) for irrigation. The recommended dose of fertilizer (RDF) 60:20:20 kg N, $\mathrm{P}_{2} \mathrm{O}_{5}$ and $\mathrm{K}_{2} \mathrm{O}$ ha $^{-1}$, respectively, for mustard. Primary nutrients were provided through urea, single super phosphate and murate of potash. Full amount of phosphorous and potash and half amount of nitrogen was applied at the time of sowing, while the remaining dose of nitrogen was applied after first irrigation. The irrigation was given and other recommended package of practice was followed during the crop growth period. Irrigation water of desired level with $\mathrm{EC}_{\text {iw }} 7 \mathrm{dSm}^{-1}$ was prepared by blending saline water taken from tube well with canal water in a mixing tank. Five randomly selected plants from each plot were uprooted for determining plant height at peak growth stage, i.e., 60 days after sowing (DAS). The yield parameters were indexed at harvest to estimate the contribution to yield. The branches of five randomly sample plants were tallied and reported as number of primary and secondary branches per plant. Similarly, the total siliqua of five sample plants were enumerated and asserted as 
number of siliquae per plant. The weight of 1000 seed counted from the lot, weighed and as 1000 seed weight (g). The seed and straw yield was estimated from the harvest of net plot and expressed in quintal ha $^{-1}$. Soil samples were analysed for nitrogen, phosphorous and potassium as per standard laboratory procedures (Jackson, 1973). Entire experimental data for different growth and yield parameters were statistically analysed by Analysis of variance (ANOVA) prescribed for the design to test the significance of overall difference among treatments by F-test and conclusions were drawn at $5 \%$ probability level.

\section{Results and Discussion}

The data presented in Table 1 indicates that the mean plant height $(\mathrm{cm})$ was significantly higher in variety CS-58 (201.1) which was at par with variety CS-54 (193.0) followed by variety Giriraj (186.3) and Kranti (179.4). Amongst fertilizer doses, application of $125 \%$ and $150 \%$ doses of fertilizer reported significantly higher plant height (189.2 and 195.7) as compared to $100 \%$ dose of fertilizer application. The maximum rate of fertilizer application, i.e., $180 \mathrm{~kg} \mathrm{~N}$ ha $^{-1}$ produced a significantly higher plant height than all other rates (AI-Solaimani et al., 2015). The preceding results could be predominantly due to the affirmative effect of nitrogen on the development of stem and leaf area which was depicted in taller plants (Cheema et al., 2001). Raghuvanshi et al. (2018) reported consubstantial increment in plant height with hike in levels of nitrogen maximum with the application of 160 $\mathrm{kg} \mathrm{Nha}^{-1}$. It may be as a result of mineral nitrogen and synthesis of carbohydrates in plant green parts which are metabolized into amino-acids and proteins responsible for faster growth of plants.

Entire yield attributing characters were statistically altered by diversified treatments combinations (Table 2, 3). The number of primary branches plant ${ }^{-1}$ recorded maximum in variety CS-54 (6.36) followed by CS-58 (6.28), Giriraj (5.79) and Kranti (5.48). Further it was observed that number of secondary branches per plant, siliqua per plant and seeds per siliqua was higher under variety CS-58 (16.46, 372.1 and 15.73) which was at par with variety CS-54 (15.89, 353.7 and 15.34). Variety Kranti recorded minimum of these attributes among all the four mustard varieties. With respect of different subplot treatments the maximum of these parameters was found with the application of $125 \%$ RDF and $150 \%$ RDF in comparison to application of recommended dose of fertilizer. Application of $150 \%$ RDF gave $40.16 \%$ more primary branches per plant, $26.89 \%$ more secondary branches per plant, $14.67 \%$ more siliqua per plant and $23.41 \%$ more seeds per siliqua compared to least application of fertilizer doses, i.e., RDF. Paliwal and Singh (2014) and Tekchand et al. (2017) reported similar results where significant high number of siliquae were reported at $150 \%$ NPK compared to other treatments. It might be due to the increased number of branches per plant which may have accredited to more number of siliqua per plant. Similar affirmative effect of accessory nutrients on yield characters was reported by Singh and Pal

Table 1 : Test weight and height of mustard varieties as influenced by fertilizer doses under saline water irrigation

\begin{tabular}{|c|c|c|c|c|c|c|c|c|}
\hline \multirow[t]{3}{*}{ Variety } & \multicolumn{8}{|c|}{ Fertilizer doses $\left(\mathrm{kg} \mathrm{ha}^{-1}\right)$} \\
\hline & \multirow[b]{2}{*}{ RDF } & \multicolumn{2}{|c|}{ Test weight } & & \multicolumn{4}{|c|}{ Plant height (cm) } \\
\hline & & $125 \%$ RDF & $150 \%$ RDF & Mean & RDF & $125 \%$ RDF & $150 \%$ RDF & Mean \\
\hline Giriraj & 5.10 & 5.23 & 5.53 & 5.29 & 180.7 & 188.0 & 190.2 & 186.3 \\
\hline Kranti & 4.77 & 5.00 & 5.10 & 4.96 & 175.1 & 178.5 & 184.7 & 179.4 \\
\hline CS-54 & 5.33 & 5.53 & 5.70 & 5.52 & 187.4 & 192.0 & 199.6 & 193.0 \\
\hline CS-58 & 5.53 & 5.73 & 5.90 & 5.73 & 193.8 & 198.5 & 208.1 & 201.1 \\
\hline Mean & 5.18 & 5.38 & 5.57 & & 184.3 & 189.2 & 195.7 & \\
\hline
\end{tabular}

$\mathrm{CD}(\mathrm{p}=0.05)$; Variety (V):NS; Fertiliser level (F):NS; $\mathrm{V} x \mathrm{~F}=\mathrm{NS}$; Variety $(\mathrm{V}): 12.1$; Fertilizer doses $(\mathrm{F}): 4.0 ; \mathrm{V} x \mathrm{~F}=\mathrm{NS}$

Table 2: Number of primary and secondary branches per plant of mustard varieties as influenced by fertilizer doses under saline water irrigation

\begin{tabular}{|c|c|c|c|c|c|c|c|c|}
\hline \multirow[t]{3}{*}{ Variety } & \multicolumn{8}{|c|}{ Fertilizer doses $\left(\mathrm{kg} \mathrm{ha}^{-1}\right)$} \\
\hline & \multicolumn{4}{|c|}{ Primary branches } & \multicolumn{4}{|c|}{ Secondary branches } \\
\hline & RDF & $125 \%$ RDF & $150 \%$ RDF & Mean & RDF & $125 \%$ RDF & $150 \%$ RDF & Mean \\
\hline Giriraj & 5.20 & 6.03 & 6.13 & 5.79 & 12.10 & 14.30 & 15.67 & 14.02 \\
\hline Kranti & 4.10 & 5.53 & 6.80 & 5.48 & 11.00 & 12.33 & 15.00 & 12.78 \\
\hline CS-54 & 5.50 & 6.43 & 7.13 & 6.36 & 14.33 & 16.33 & 17.00 & 15.89 \\
\hline CS-58 & 4.73 & 6.80 & 7.30 & 6.28 & 14.33 & 17.00 & 18.03 & 16.46 \\
\hline Mean & 4.88 & 6.20 & 6.84 & & 12.94 & 14.99 & 16.42 & \\
\hline
\end{tabular}

$\mathrm{CD}(\mathrm{p}=0.05)$; Variety (V):NS; Fertilizer doses ( $\mathrm{F}): 0.47 ; \mathrm{VxF}=\mathrm{NS}$; Variety $(\mathrm{V}): 2.14$; Fertiliser level $(\mathrm{F}): 0.84 ; \mathrm{VxF}=\mathrm{NS}$ 
Table 3 : Number of siliqua per plant and seed per siliqua of mustard varieties as influenced by fertilizer doses under saline water irrigation

\begin{tabular}{|c|c|c|c|c|c|c|c|c|}
\hline \multirow[t]{3}{*}{ Variety } & \multicolumn{8}{|c|}{ Fertilizer doses $\left(\mathrm{kg} \mathrm{ha}^{-1}\right)$} \\
\hline & \multicolumn{4}{|c|}{ Number of siliqua per plant } & \multicolumn{4}{|c|}{ Number of seeds per siliqua } \\
\hline & RDF & $125 \%$ RDF & $150 \%$ RDF & Mean & RDF & $125 \%$ RDF & $150 \%$ RDF & Mean \\
\hline Giriraj & 318.2 & 345.3 & 360.1 & 341.2 & 12.93 & 14.83 & 16.23 & 14.67 \\
\hline Kranti & 248.0 & 285.0 & 301.3 & 278.1 & 12.03 & 14.30 & 15.33 & 13.89 \\
\hline CS-54 & 339.0 & 355.0 & 367.0 & 353.7 & 13.83 & 15.80 & 16.40 & 15.34 \\
\hline CS-58 & 340.7 & 375.2 & 400.3 & 372.1 & 14.00 & 16.00 & 17.20 & 15.73 \\
\hline Mean & 311.5 & 340.1 & 357.2 & & 13.20 & 15.23 & 16.29 & \\
\hline
\end{tabular}

$\mathrm{CD}(\mathrm{p}=0.05) \quad$ Variety $(\mathrm{V}): 62.5$; Fertiliser level $(\mathrm{F}): 31.5 ; \mathrm{V} \times \mathrm{F}=\mathrm{NS} \quad$ Variety $(\mathrm{V}): 0.51$; Fertiliser level:0.92; $\mathrm{V} \times \mathrm{F}=\mathrm{NS}$

Table 4 : Seed and straw yield of mustard varieties as influenced by fertilizer doses under saline water irrigation

\begin{tabular}{|c|c|c|c|c|c|c|c|c|}
\hline \multirow[t]{3}{*}{ Variety } & \multicolumn{8}{|c|}{ Fertilizer doses $\left(\mathrm{kg} \mathrm{ha}^{-1}\right)$} \\
\hline & \multicolumn{4}{|c|}{ Seed yield ( $q$ ha $\left.^{-1}\right)$} & \multicolumn{4}{|c|}{ Straw yield (q ha ${ }^{-1}$ ) } \\
\hline & RDF & $125 \%$ RDF & $150 \%$ RDF & Mean & RDF & $125 \%$ RDF & $150 \%$ RDF & Mean \\
\hline Giriraj & 16.09 & 17.59 & 17.99 & 17.22 & 53.97 & 61.56 & 72.29 & 62.60 \\
\hline Kranti & 14.70 & 16.12 & 17.72 & 16.18 & 49.12 & 56.42 & 69.01 & 58.18 \\
\hline CS-54 & 17.41 & 18.13 & 20.94 & 18.23 & 58.60 & 66.97 & 76.79 & 67.45 \\
\hline CS-58 & 20.92 & 21.72 & 22.89 & 21.84 & 69.71 & 77.20 & 88.33 & 78.41 \\
\hline Mean & 17.28 & 18.39 & 19.89 & & 57.85 & 65.54 & 76.60 & \\
\hline
\end{tabular}

$C D(p=0.05)$; Variety (V):0.91; Fertilizer doses $(F): 0.44 ; V x F=0.87 ;$ Variety: $2.02 ;$ Fertilizer doses: $1.00 ; V x F: N S$

Table 5 : Economic analysis of different mustard varieties (Rs. ha $\left.{ }^{-1}\right)$ in Hisar district of Haryana

\begin{tabular}{llllll}
\hline Verity/Treatment & \multicolumn{3}{c}{ Giriraj } \\
\cline { 2 - 6 } combinations & Cost of Cultivation & Gross return & Return over variable cost & Net return & B:C ratio \\
\hline RDF & 51154 & 69757 & 43603 & 18603 & 1.36 \\
$125 \%$ RDF & 51989 & 76516 & 49527 & 24527 & 1.47 \\
$150 \%$ RDF & 52898 & 79189 & 51291 & 26291 & 1.50 \\
& & & Kranti & 12558 & 1.25 \\
RDF & 51154 & 63712 & 37558 & 18133 & 1.35 \\
$125 \%$ RDF & 51989 & 70122 & 43133 & 24883 & 1.47 \\
$150 \%$ RDF & 52898 & 77781 & 49883 & & 1.48 \\
RDF & CS-54 & & & 24346 & 1.52 \\
$125 \%$ RDF & 51154 & 75500 & 49346 & 38541 & 1.73 \\
$150 \%$ RDF & 51989 & 79217 & 52228 & & 1.77 \\
RDF & 52898 & 91439 & 63541 & 39497 & 1.82 \\
$125 \%$ RDF & CS-58 & & & 42611 & 1.90 \\
$150 \%$ RDF & 51154 & 90651 & 64497 & 47495 & \\
\hline
\end{tabular}

(2011). The noteworthy value of yield attributes is the result of higher fertility levels resulted into better growth and higher translocation of photosynthates from source to sink (Raghuvanshi et al., 2018; Tripathi et al., 2010; Rana et al., 2005). The results also revealed that 1000 seed weight failed to generate any significant response with any treatment combination, moreover maximum test weight was recorded in variety CS-58 on application of $150 \%$ RDF.
Significantly maximum seed and straw yield was recorded in variety CS-58 (21.84 and $\left.78.41 \mathrm{q} \mathrm{ha}^{-1}\right)$ followed by variety CS-54 (18.23 and $67.45 q^{\text {q ha }}{ }^{-1}$ ), Giriraj (17.22 and $62.60 \mathrm{q}$ ha $^{-1}$ ) and Kranti (16.18 and $\left.58.18 \mathrm{q} \mathrm{ha}^{-1}\right)$. Amongst subplot treatments, $125 \%$ (18.39 and $65.54 \mathrm{q} \mathrm{ha}^{-1}$ ) and 150\% RDF (19.89 and $76.60 \mathrm{q} \mathrm{ha}^{-1}$ ) recorded significantly higher seed and straw yields than minimum applied of fertilizer, i.e., RDF. Application of 150\% RDF gave 15.10 and 32.41 per cent more seed and straw 
yield compared to $100 \%$ dose of fertilizer. Further interaction between varieties and fertilizer doses was reported significant in which the combination $\mathrm{V}_{4} \mathrm{~F}_{3}$ (CS-58 at 150\% RDF) reported significantly maximum seed yield $\left(22.89 q \mathrm{q}^{-1}\right)$, followed by the treatment $\mathrm{V}_{4} \mathrm{~F}_{2}$ [CS-58 $\left(21.72 \mathrm{q} \mathrm{ha}^{-1}\right)$ at $125 \%$ RDF], $\mathrm{V}_{3} \mathrm{~F}_{3}$ [CS-54 $\left(20.94 \mathrm{q} \mathrm{ha}^{-1}\right)$ at $150 \% \mathrm{RDF}$ ] and $\mathrm{V}_{4} \mathrm{~F}_{1}$ [CS-58 $\left(20.92 \mathrm{q} \mathrm{ha}^{-1}\right)$ at RDF]. The lowest seed yield ( $14.70 q$ ha $\left.^{-1}\right)$ was obtained under treatment $\mathrm{V}_{2} \mathrm{~F}_{1}$ (Kranti at RDF) followed by the treatment $\mathrm{V}_{1} \mathrm{~F}_{1}$ [Giriraj (16.09 $\left.\mathrm{q} \mathrm{ha}^{-1}\right)$ at RDF], $\mathrm{V}_{2} \mathrm{~F}_{2}$ [Kranti (16.12 $\mathrm{q}$ ha $\left.{ }^{-1}\right)$ at $125 \%$ RDF], $\mathrm{V}_{1} \mathrm{~F}_{2}$ [Giriraj (17.59 $\mathrm{q}$ ha ${ }^{-1}$ ) at $\left.125 \% \mathrm{RDF}\right]$ and $\mathrm{V}_{2} \mathrm{~F}_{3}$ [Kranti $\left(17.72 \mathrm{q} \mathrm{ha}^{-1}\right)$ at $150 \%$ RDF]. The seed and straw yield increased with increased number of leaves causing higher photosynthesis and assimilation rates, metabolic activity and cell division, which were responsible for significant increase in yield attributes and yield of Indian mustard (Singh et al., 2014; Pattam et al., 2017). The higher seed yield and stover yield was due to better expression of growth and yield attributes which led to increased yield (Singh et al., 2010; Yadav and Dhanai, 2018; Raghuvanshi et al., 2018). Similar results were reported by many researchers (Shukla et al., 2002; Premi and Kumar, 2004; Singh and Pal, 2011; Shekhawat etal., 2012).

Treatment wise economics of different mustard variety is depicted in Table 5. The results revealed that all the treatments and varieties were found economically positive but $150 \%$ RDF proved to be economically beneficial with highest net returns of Rs. 26,291, 24,883, 38,541, 47,495 ha ${ }^{-1}$ and B: C ratio 1.50, 1.47, 1.73 and 1.90 in variety Giriraj, Kranti, CS-54 and CS- 58, respectively. Whereas, CS- 58 variety among all four mustard varieties with treatment $150 \%$ RDF was found to be economically significant with highest net return of Rs. $47495 \mathrm{ha}^{-1}$ and benefit to cost ratio (B: C) of 1.90. Roul et al. (2006) reported higher monitory advantage from 100\% RDF blended with farmyard manure. Singh et al. (2010) also investigated the effect of different fertility level on performance of Indian mustard under late sown condition recorded the highest net return and benefit: cost ratio which was at par in 'Varuna' (V3) and 'Kranti' (V1) both the years under study, but the values obtained for both the parameters were significantly higher than 'Vardan' (V2) in the first year, and 'Ashirwad' (V5) as well as 'Vardan' (V2) in the second year. Mustard variety i.e. CS- 58 in comparison to other varities viz. Kranti, Giriraj, and CS-54 has proved to be more effective under saline conditions along with the application of $150 \%$ RDF with improved growth, and yield, and better economic returns.

\section{Acknowledgment}

The authors are grateful to the Head, Department of Soil Science, CCS HAU, Hisar for providing the instrumental facilities and helping during formulation of research project.

\section{References}

Abbasi, H., M. Jamil, A. Haq, S. Ali, R. Ahmad, Z. Malik and Z. Parveen: Salt stress manifestation on plants, mechanism of salt tolerance and potassium role in alleviating it: A review. Zemdirbyste., 103, 229-238 (2016).

Abumere, V.I., O.A. Dada, A.G. Adebayo, F.R. Kutu and A.O. Togun: Different rates of chicken manure and NPK 15-15-15 enhanced performance of sunflower (Helianthus annuus $L$.) on ferruginous soil. Int. J. Agron., 4, 1-10 (2019).

Al-Solaimani, S.G., F. Alghabari and M.Z. Insan: Effect of different rates of nitrogen fertilizer on growth, seed yield, yield components and quality of canola (Brassica napus L.) under arid environment of Saudi Arabia. Int. J. Agron. Agric. Res., 6, 268-274 (2015).

Ashraf, M. and T. McNeilly: Salinity tolerance in brassica oilseeds. Crit. Rev. Plant. Sci., 23,157-174 (2004).

Chauhan, C.P.S., R.B. Singh and S.K. Gupta: Supplemental irrigation of wheat with saline water. Agric. Water. Manag., 95, 253-258 (2008).

Cheema, M.A., M.A. Malik, A. Hussain, S.H. Shah and S.M.A. Basra: Effects of time and rate of nitrogen and phosphorus application on the growth and the seed and oil yields of canola (Brassica napus L.). J. Agron. Crop Sci., 186, 103-110 (2001).

Gupta, S.K. and I.C. Gupta: Management of saline and waste water in agriculture. Scientific Publishers (2015).

Jackson, M.L.: Soil Chemical Analysis. $2^{\text {nd }}$ Indian Print., Prentice-Hall of India Pvt. Ltd. New Delhi., pp. 38-336 (1973).

Kumar, R., V. Goyal and M.S. Kuhad: Influence of fertility-salinity interactions on growth, water status and yield of Indian mustard (Brassicajuncea). Indian J. Plant Physiol., 10, 139 (2005).

Mahmood, K.: Salinity tolerance in barley (Hordeum vulgare L.): Effects of varying $\mathrm{NaCl}, \mathrm{K}^{+} / \mathrm{Na}^{+}$and $\mathrm{NaHCO}_{3}$ levels on cultivars differing in tolerance. Pak. J. Bot., 43, 1651-1654 (2011).

Paliwal, A. and J.P. Singh: Response of mustard (Brassica juncea L.) Czernj. Cosson) to potassium with other nutrients on yield and quality. The Bioscan, 9, 649-652 (2014).

Pattam, K., R.K. Pannu, A.K. Dhaka and K.D. Sharma: Effect of dates of sowing and nitrogen levels on growth and yield of Indian mustard. Int. J Curr. Microbiol. App. Sci., 6,1029-1036 (2017).

Premi, O.P. and M. Kumar: Response of Indian mustard to different levels of nitrogen and phosphorus under rainfed condition. Indian J. Agron., 38, 47-48 (2004).

Raghuvanshi, N., V. Kumar and J. Dev: Effect of nitrogen levels on mustard (Brassica juncea (L.) Cuzern and Coss.) varieties under late sown condition. Curr. J. Appl. Sci. Tech., 30, 1-8 (2018).

Rana, K.S., D.S. Rana and R.C. Gautam: Influence of phosphorus, sulphur and boron on growth, yield, nutrient uptake and economics of Indian mustard (Brassica juncea) under rainfed conditions. Indian J. Agron., 50, 314-316 (2005).

Roul, P.K., S.K. Sarawgi, G.K. Shrivastav and D. Kumar: Effect of integrated nitrogen management techniques on productivity, nitrogen uptake, $\mathrm{N}$-use efficiency, economics and energetics of rice (Oryza sativa)-Indian mustard (Brassica juncea) sequence. Indian J.Agron., 51, 170-173 (2006).

Sharma, P., V. Sardana and S.S. Banga: Salt tolerance of Indian mustard (Brassica juncea) at germination and early seedling growth. Environ. Exper. Biol., 11, 39-46 (2013).

Shekhawat, K., S.S. Rathore, O.P. Premi, B.K. Kandpal and J.S. Chauhan: Advances in agronomic management of Indian mustard (Brassica juncea (L.) Czernj. Cosson): An overview. Int. J. Agron., (2012).

Shukla, R.K., A. Kumar, B.S. Mahapatra and B. Kandpal: Integrated nutrient management practices in relation to morphological and physiological determinants of seed yield in Indian mustard (Brassicajuncea). Indian J. Agric. Sci., 72, 670-672 (2002). 
Singh, R.K., Y. Singh, A.K. Singh, R. Kumar and V.K. Singh: Productivity and economics of mustard (Brassica juncea) varieties as influenced by different fertility levels under late sown condition. Indian J. Soil Conserv., 38, 121-124 (2010).

Singh, R., A.K. Singh and P. Kumar: Performance of Indian mustard (Brassica juncia L.) in response to integrated nutrient management. Indian J. Agric. Res., 1, (2014).

Singh, S.P. and M.S. Pal: Effect of integrated nutrient management on productivity, quality, nutrient uptake and economics of mustard (Brassicajuncea). Indian J. Agron., 56, 381-387 (2011).

Tekchand, C., S. Devendra and B.L. Jat: Response of mustard to potassium in combination with other nutrients. Asian J. Hort., 12, 169-184 (2017).

Tripathi, M.K., S. Chaturvedi, D.K. Shukla and B.S. Mahapatra: Yield performance and quality in Indian mustard (Brassica juncea) as affected by integrated nutrient management. Indian J. Agron., 55, 138-142 (2010).

USDA: http://apps.fas.usda.gov. Foreign Agricultural Service (FAS), U. S. Department of Agriculture (2019)

Yadav, M.S. and C.S. Dhanai: Effect of fertilizers on yield and yield attributing characters of mustard (Brassica juncea L. Czern and Coss). J. Pharmacogn. Phytochem., 7, 2300-2303 (2018). 